\title{
PRESENT CONDITION OF MANGROVE ENVIRONMENTS AND COMMUNITY STRUCTURE IN TOMINI GULF, SULAWESI, INDONESIA
}

\section{KONDISI LINGKUNGAN DAN STRUKTUR KOMUNITAS MANGROVE DI TELUK TOMINI, SULAWESI, INDONESIA}

\author{
Rignolda Djamaluddin $^{1 *}$, Muhamad A. Kaumbo ${ }^{2}$ and Brama Djabar ${ }^{2}$ \\ ${ }^{1}$ Study Program of Marine Science, FPIK-UNSRAT, Manado, 95115, Indonesia \\ ${ }^{2}$ Perkumpulan Kelola, Manado, 95115, Indonesia \\ *E-mail: rignolda@unsrat.ac.id
}

\begin{abstract}
The mangroves in Tomini Gulf have been exploited for chiefly conversion of mangrove areas into shrimp cultivation and extraction of mangrove wood for various purposes. In this study, interpretation to available map and satellite images and ground check were conducted to describe intertidal environment conditions and general processes of coastal dynamic. At local scale, physiographic factors were used to classify mangrove sub-habitats. A total of 159 sample points were selected to observe structure of vegetation, and the revised two ways classification of Specht was applied to classify structural classification of vegetation. The criterion of mangrove disturbance was developed to classify disturbance level. Interview and field check were conducted to assess the successfulness of implemented rehabilitation programs. Results indicated that there were obvious changes in mangrove vegetation over much the intertidal environments, and these might influence the future development and regeneration of the mangroves. While most rehabilitation programs were unsuccessful, mangrove exploitations still continued. If a sustainable management plan is not developed, the degradation will continue and spread, and the mangrove will lose its ecological functions.
\end{abstract}

Keywords: disturbance, mangrove, shrimp cultivation, Tomini Gulf

\begin{abstract}
ABSTRAK
Mangrove di Teluk Tomini telah dieksploitasi terutama lahannya dikonversi menjadi tambak udang dan pohonnya ditebang untuk beragam tujuan. Dalam studi ini interpretasi terhadap peta dan citra satelit dilakukan untuk mendeskripsikan kondisi lingkungan intertidal dan proses-proses terkait dinamika pantai secara umum. Pada skala lokal, faktor fisiografik digunakan untuk mengklasifikasikan sub-habitat mangrove. Sebanyak 159 titik sampel dipilih untuk mengamati struktur vegetasi, dan klasifikasi dua-arah Specht yang telah direvisi untuk mangrove digunakan untuk mengelompokkan kelas struktur vegetasi. Kriteria kerusakan mangrove dikembangkan untuk mengklasifikasikan tingkat kerusakan. Wawancara dan pengamatan lapangan dilakukan untuk menilai keberhasilan program rehabilitasi. Hasil studi menunjukkan bahwa telah terjadi perubahan nyata pada vegetasi mangrove di Teluk Tomini, dan perubahan ini dapat mempengaruhi perkembangan dan regenerasi mangrove selanjutnya. Eksploitasi mangrove masih terus berlangsung, sementara kebanyakan program rehabilitasi mangrove tidak berhasil. Jika rencana pengelolaan berkelanjutan tidak dikembangkan, maka dikawatirkan kerusakan akan terus berlangsung dan meluas, dan mangrove di Teluk Tomini akan kehilangan fungsi ekologisnya.
\end{abstract}

Kata kunci: kerusakan, mangrove, tambak udang, Teluk Tomini

\section{INTRODUCTION}

Mangrove is the term used for those species, a relative small group of higher plants, or the whole community of plants, which have been peculiarly successful in colonising tropical and sub-tropical intertidal habitats at the interface between land and sea (Maxwell, 2015). Global distribution of mangrove have been explained in various 
reports (Gieasen et al., 2006; Spalding et al., 2010; Hamilton and Casey, 2016; Richards and Friess, 2016). Southeast Asia supports the world's largest area of mangroves, originally extending over 5.1 million ha (Spalding et al., 2010). The largest areas of mangrove in Southeast Asia are found in Indonesia with almost $60 \%$ of Southeast Asia's total (Gieasen et al., 2006).

Mangroves provide biomass and contribute to productivity that is of substantial benefit to human populations, primarily fisheries and forestry products (Bandaranayake, 1998). Other critical ecosystem services that mangroves provide include coastline protection (Koch et al., 2009) and mitigation of climate change effects (Murdiyarso et al., 2015). Despite all the ecological services and economic benefits associated with mangrove ecosystems, about $2.1 \%\left(2,834 \mathrm{~km}^{2}\right)$ of the existing worldwide mangrove area was estimated to be lost each year during the second half of the $20^{\text {th }}$ century (Valiela et al., 2001) and a total loss of $1.97 \%\left(1,646 \mathrm{~km}^{2}\right)$ from 2000 to 2012 (Hamilton and Casey, 2016). In Indonesia, mangrove deforestation rate was measured at 0.05 million ha per year (Margono et al., 2014).

Mangroves in Tomini Gulf occur along almost all intertidal environments. These ecosystems are unique, growing close to the equator. The total area of mangrove in the Gulf is of some 16,105.40 ha. Unfortunately, within the last two decades the Gulf has lost $10,787.55$ ha of its mangrove ecosystems due to mainly conversion the ecosystems into shrimp cultivation that is locally called tambak udang (Damanik and Djamaluddin, 2012).

Mangrove environments are of susceptible to both natural and human pressures (Hendrawan et al., 2018). Considering the ecological values that the mangroves of Tomini Gulf can provide, and the continuous damage that the mangroves experience, a lot of effort is needed in order to reduce the damage and to restore the ecological functions of these ecosystems. Accordingly, comprehensive baseline data and information are needed to support the development of a sustainable mangrove management plan. This study was conducted to describe intertidal environmental conditions and variation in sub-habitat types of mangroves, to investigate conditions of vegetation structure in relation to patterns of uses and level of disturbances, and to assess any applied mangrove rehabilitation programs in Tomini Gulf.

\section{RESEARCH METHODS}

\subsection{Time and Study Locations}

Field observation was conducted during 2009 to 2015 covering all mangrove areas in between $1.5^{\circ} \mathrm{S}$ and $0.6^{\circ} \mathrm{N} ; 120^{\circ}$ and $125^{\circ} \mathrm{E}$ that included Regencies of Bolaang Mongondow Selatan, Boalemo, Pohuwato, and Parigi Moutong. A total of 159 sample points (Figure 1) representing various types and conditions of mangrove were sellected for deep investigation.

\subsection{Data Collection and Analysis \\ 2.2.1. Intertidal Habitat Formations and Classification of Sub-Habitat Types \\ Available maps (Peta Rupa Bumi} Indonesia, 1:50.000 scale) and data from images (Landsat 4-5 TM and Landsat 7 ETM+) were analysed to describe intertidal environment conditions and general processes of coastal dynamic in Tomini Gulf. Results of analysis were confirmed through ground checks. At local scale, all sub-habitat types were classified based primarily on dominant physiographic factors proposed by Clarke and Hannon (1969), including tidal inundation, substrate condition, and freshwater inflow. General characteristics of sediment were observed visually, and a measuring stake was used to determine the depth of surface substrate. The depth of surface substrate was classified into three classes i.e., shallow (less than $30 \mathrm{~cm}$ ), 
medium $(30-50 \mathrm{~cm})$, and deep (more than $50 \mathrm{~cm})$.

\subsubsection{Description of Vegetation Structure}

A total 159 sample points were visited to investigate growth habit, canopy stratum, canopy form, canopy height, canopy cover, canopy evenness, number of cutting tree in $10 \mathrm{~m}^{2}$, tree diameter, and distribution of diameter. The mangrove species within $100 \mathrm{~m}$ radius around each sample point were recorded to allow a floristic classification. Field identification of the flora was based on specimens' morphology, and these were compared to several mangrove references (Ding Hou, 1958; Percival and Womersley, 1975; Fernando and Pancho, 1980; Blasco, 1984; Tomlinson, 1986; Mabberley et al., 1995; Noor et al., 2006).

Canopy height was measured directly by means of a fixed stick for a tree with height up to $4 \mathrm{~m}$, and for a tree more than 4 $\mathrm{m}$, it was indirectly measured using the formula $\left(\tan a^{o} x d\right)+h$, where $a^{o}$ is the angle between observer and top of tree canopy, $\mathrm{d}$ is the distance between observer and tree, $h$ is observer's height. Tree diameter was calculated based on formula of tree's girth divided by 3.14. A tree's girth was measured by means of plastic tape at breast height (a tree with a single stem), above the highest still root (a large Rhizophora spp.), about $50 \mathrm{~cm}$ from the base (a tree with two main branches sprouting out near the base), and just below the lowest branches (a tree with many branches as in Scyphyphora hydrophyllacea).

Foliage Projective Cover (FPC) was assesed using across wire on a free swinging vertical tube with a $45^{\circ}$ mirror, developed by Winkword and Goodall (1962). The two ways classification of Specht (1970) which have been revised for mangroves (Walker and Hopkins, 1990; Djamaluddin, 2004) were applied to classify the structural classification of vegetation (Table 1).

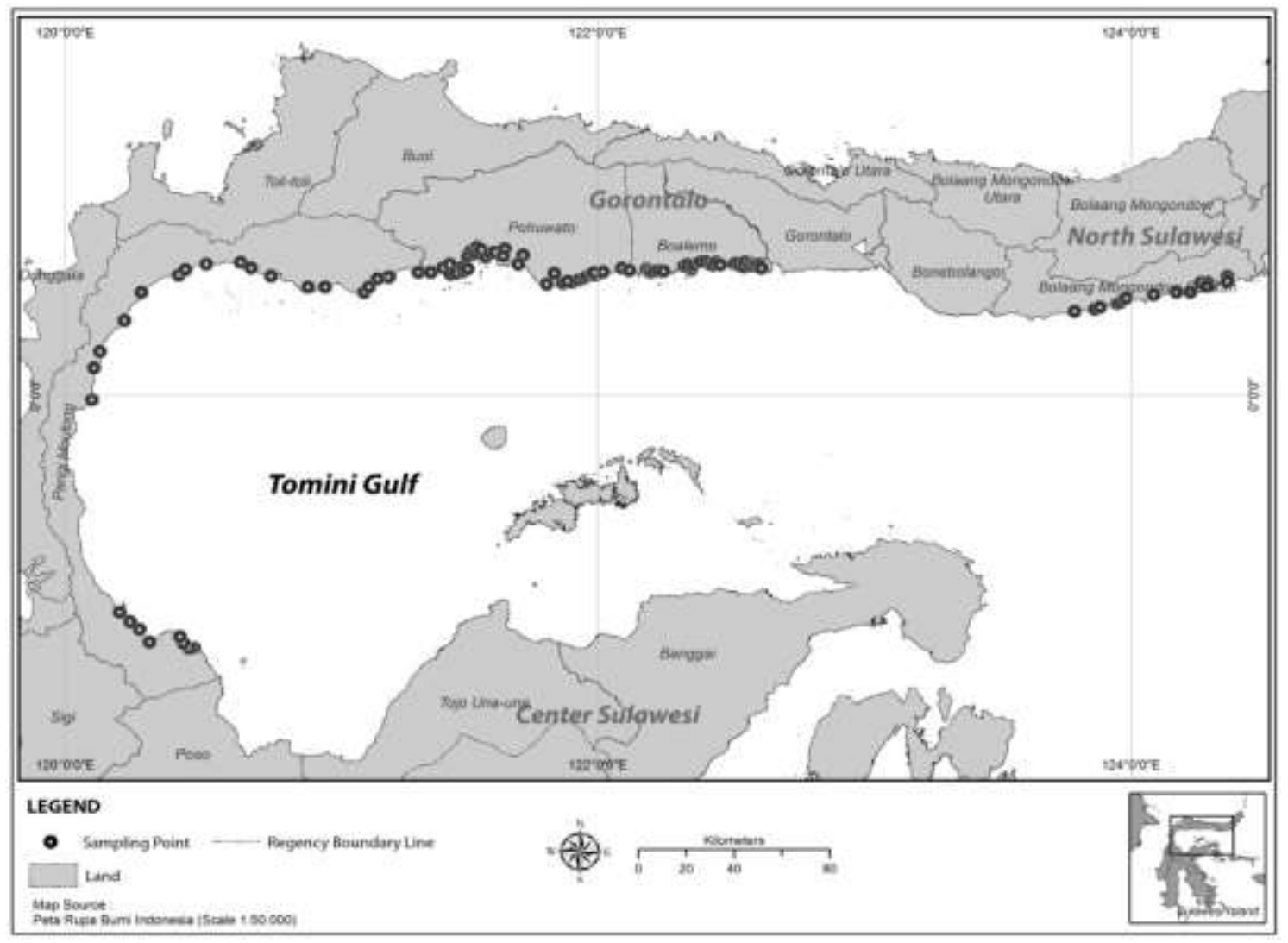

Figure 1. Map of the study location and sample points of observation. 
Tabel 1. The most common structural formations of mangrove plant commmunities.

\begin{tabular}{llllll}
\hline \multirow{2}{*}{ FPC $(\%)$} & \multicolumn{5}{c}{ Life form/Height of Uppermost Stratum } \\
\cline { 2 - 6 } & \multicolumn{1}{c}{ Tree $^{1}$} & \multicolumn{1}{c}{ Tree } & \multicolumn{1}{c}{ Tree } & \multicolumn{1}{c}{ Shrub } & \multicolumn{1}{c}{ Shrub } \\
& $>30 \mathrm{~m}$ & $10-30 \mathrm{~m}$ & $2-10 \mathrm{~m}$ & $2-8 \mathrm{~m}$ & $<2 \mathrm{~m}$ \\
\hline $\begin{array}{l}\text { Dense 100- } \\
70\end{array}$ & $\begin{array}{l}\text { Tall closed- } \\
\text { forest }\end{array}$ & $\begin{array}{l}\text { Closed- } \\
\text { forest }\end{array}$ & $\begin{array}{l}\text { Low closed- } \\
\text { forest }\end{array}$ & $\begin{array}{l}\text { Tall closed- } \\
\text { shrub }\end{array}$ & $\begin{array}{l}\text { Low closed- } \\
\text { shrub }\end{array}$ \\
$\begin{array}{l}\text { Mid-dense } \\
70-50\end{array}$ & Tall forest & Forest & Low forest & Tall shrub & Low shrub \\
Mid-dense & Tall open- & Open-forest & Low open- & Tall open- & Low open- \\
50-30 & forest & & forest & shrub & shrub \\
Sparse 30- & & & & Tal sparse- & Low sparse- \\
10 & - & - & - & shrub & shrub \\
\hline
\end{tabular}

${ }^{1} \mathrm{~A}$ tree is defined as larger woody plant usually with a single stem

${ }^{2} \mathrm{~A}$ shrub is defined as smaller woody plant usually with many stems arising at or near the base

2.2.3. Classification of Forest Disturbance canopy form, canopy cover and number of Structural attributes of diameter tree cutting were used to classify forest distribution, growth habit, canopy stratum, disturbance as summarised in Table 2 .

Table 2. Criterion of mangrove forest disturbance.

\begin{tabular}{|c|c|c|c|c|c|c|}
\hline \multirow[b]{2}{*}{$\begin{array}{c}\text { Disturbance } \\
\text { Level }\end{array}$} & \multicolumn{6}{|c|}{ Indicators } \\
\hline & $\begin{array}{c}\text { Tree } \\
\text { Cutting } \\
(\%)\end{array}$ & $\begin{array}{c}\text { Diameter } \\
\text { Distribution }\end{array}$ & Growth Habit & $\begin{array}{l}\text { Canopy } \\
\text { Stratum }\end{array}$ & $\begin{array}{l}\text { Canopy } \\
\text { Form }\end{array}$ & $\begin{array}{c}\text { Canopy } \\
\text { Cover } \\
(\%)\end{array}$ \\
\hline Very light & $\begin{array}{l}\text { Less than } \\
5 \text { stems }\end{array}$ & Even & $\begin{array}{l}\text { Commonly } \\
\text { single-stemmed }\end{array}$ & Even & $\begin{array}{l}\text { From uper } \\
\text { third }\end{array}$ & $75-100$ \\
\hline Light & $\begin{array}{l}5-25 \\
\text { stems }\end{array}$ & Even & $\begin{array}{l}\text { Commonly } \\
\text { single-stemmed }\end{array}$ & Even & $\begin{array}{l}\text { From uper } \\
\text { third }\end{array}$ & $75-100$ \\
\hline Medium & $\begin{array}{l}25-50 \\
\text { stems }\end{array}$ & Uneven & $\begin{array}{l}25 \% \text { trees with } \\
\text { multi-stemmed } \\
\text { and latteral } \\
\text { coppicing }\end{array}$ & Uneven & $\begin{array}{l}50 \% \text { from } \\
\text { two-third } \\
\text { and or base }\end{array}$ & $50-75$ \\
\hline Heavy & $\begin{array}{l}50-75 \\
\text { stems }\end{array}$ & Uneven & $\begin{array}{l}\text { Commonly tree } \\
\text { with multi- } \\
\text { stemmed and } \\
\text { latteral } \\
\text { coppicing }\end{array}$ & Uneven & $\begin{array}{l}\text { Commonly } \\
\text { from two- } \\
\text { third and } \\
\text { or base }\end{array}$ & $25-50$ \\
\hline $\begin{array}{l}\text { Very } \\
\text { heavy }\end{array}$ & $\begin{array}{l}\text { More } \\
\text { than } 75 \\
\text { stems }\end{array}$ & Uneven & $\begin{array}{l}\text { Commonly tree } \\
\text { with multi- } \\
\text { stemmed and } \\
\text { latteral } \\
\text { coppicing }\end{array}$ & Uneven & $\begin{array}{l}\text { Commonly } \\
\text { from two- } \\
\text { third and } \\
\text { or base }\end{array}$ & 25 \\
\hline
\end{tabular}

Note: open mangrove area was categorised in very heavy disturbance. 


\subsubsection{Assessment of Implemented Rehabilitation Programs}

Interviews with people who might have information relavent to assessing rehabilitation programs were conducted. Problems related to implemented rehabilitation programs were also identified in the field. General knowledge of biology and ecology of mangrove species, reports and references of rehabilitation techniques (Lewis, 2005; Priyono, 2010; Hidayat, 2013; Wibisono, 2016; Brown and Djamaluddin, 2017), were all used to identify and explain the identified problems.

\section{RESULT AND DISCUSSION}

\subsection{Coastal Geomorphological Processes and Habitat Types}

Differences in oceanography factors mainly wave actions that were generated from different directions and speeds of seasonally winds were expected to be the major controlling factors of coastal geomorphological processes in the Gulf. Coastal environments located near the mouth of the Gulf (areas between Bolaang Mongondow Selatan and part of Boalemo) were under influence by the seasonally strong South, South - east and East winds that could generate strong wave actions in the coastal environments and then active coastal currents. These conditions supported a common coastal formation of narrow and steep littoral zone with hard substrate type (Figure 2 B, C), a rocky cliff coast in certain locations (Figure 2 D), and a very stable small gulf-like coastal formation in sheltered location (Figure 2 A). Within the Gulf to the North (area between Pohuwato and the North part of Parigi Moutong), geomorphological processes were much influenced by the seasonal East and South - east winds that could generate active coastal currents and sedimentation westward. These conditions supported the formations of a broader, shallow, and flat intertidal environment, as well as seaward beaches in several locations
(Figure 2 F, G). An area with indication of abrasion was found at Tanjung Panjang (Figure $2 \mathrm{E}$ ). The innert side to the West (West part area of Parigi Moutong) received a strong wave surge generated by the seasonal East wind. Coastal environments in this location did not support the establishment of stable mangrove habitats (Figure 2 I, J). Within the Gulf to the South (South part area of Parigi Moutong) there was an inactive wave surge, and this supported the formation of a broad intertidal zone (Figure $2 \mathrm{~K}, \mathrm{~L}$ ).

Based on physiographic factors, subhabitat types of mangrove in Tomini Gulf could be classified into at least nine subhabitat types (Table 3).

According to Thom (1967, 1982), coastal geomorphological diversity correlates with local mangrove distribution. Previous reports also indicated that identity and diversity of mangroves varied with habitat conditions (Djamaluddin, 2015; Djamaluddin, 2018). Mangroves of Tomini Gulf was floristically rich where at least 27 species were identified, comparing to 32 species listed by Tomlinson (1986) for the broader longitudinal biogeographic region between $120^{\circ}$ and $135^{\circ} \mathrm{E}$.

Using the record by Davie et al. (1996) and Djamaluddin $(2004,2018)$ for the mangrove flora in Bunaken Nasional Park $\left(1^{\circ} 35^{\prime} 41^{\prime \prime}\right.$ and $1^{\circ} 16^{\prime} 44^{\prime \prime} \mathrm{N} ; 124^{\circ} 32^{\prime} 22^{\prime \prime}$ ' and $124^{\circ} 50^{\prime} 50^{\prime}$ 'E), five species (Avicennia alba, Champtostemon philippinense, Bruguiera sexangula, Sonneratia ovata, and Ceriops zippeliana, formerly recognised as Ceriops decandra in the majority of its range (Sheue et al., 2009; Duke et al., 2010), did not occur in Tomini Gulf. Meanwhile, species of Osbornia octodonta, Pempis acidula and Heritiera globulus seemed to be typical species of Tomini Gulf. Figure 3 describes the relative position of mangrove subhabitats across intertidal environment and the variety of species composition at different sub-habitat types. 


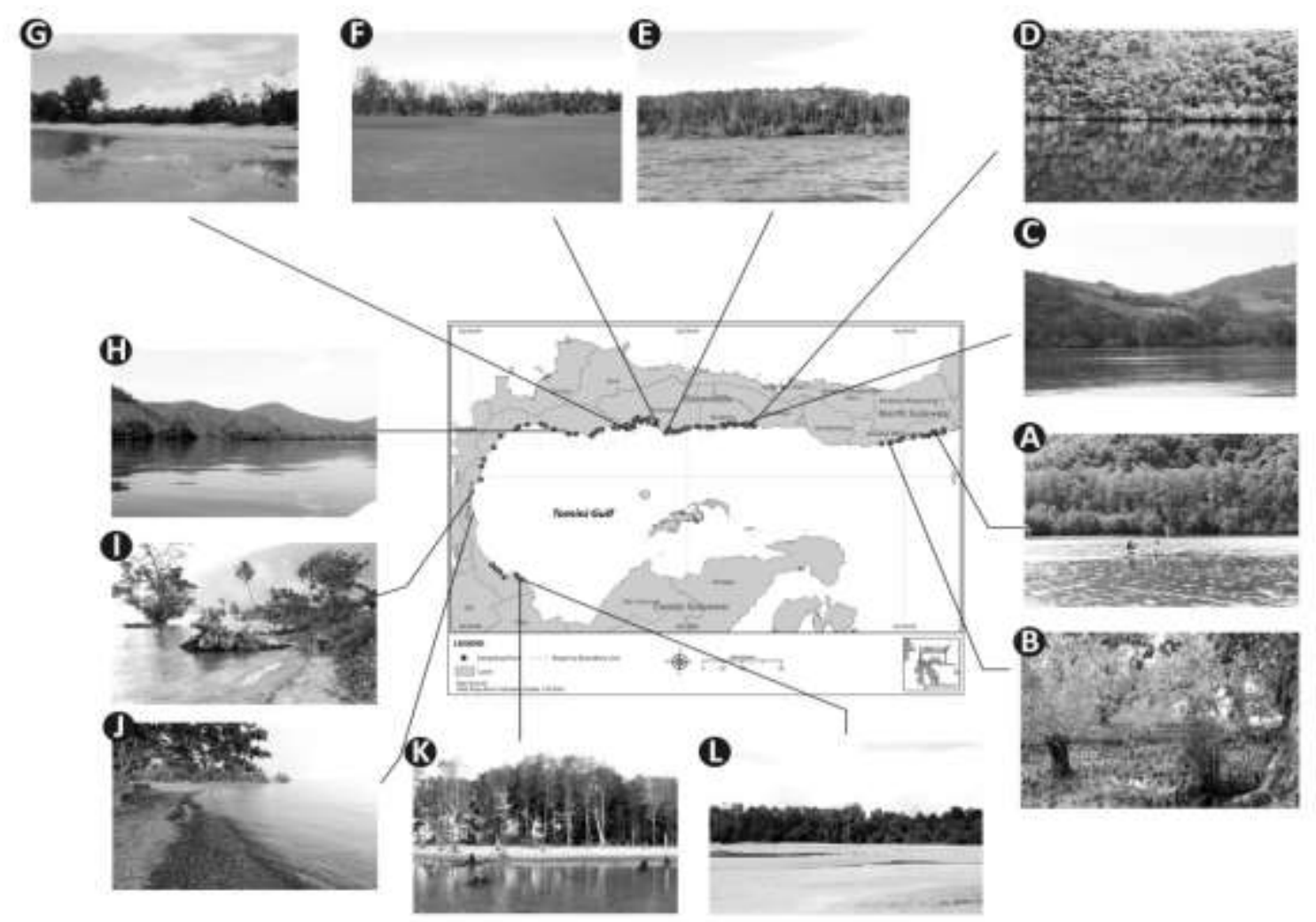

Figure 2. Coastal environment variations in Tomini Gulf: (A) very stable gulf-like coast, (B, C) narrow littoral zone with hard substrate, (D) rocky cliff coast, (E) seaward beach subjected to abrasion, (F, G) broader, shallow, flat coast subjected to sedimentation, $(\mathrm{H})$ estuary, (I, J) unstable coastal environment subjected to abrasion, (K, L) broader intertidal zone.

Table 3. Physical characteristics of sub-habitat types in Tomini Gulf.

\begin{tabular}{|c|c|c|c|c|}
\hline $\begin{array}{l}\text { Sub-habitat } \\
\text { Types }\end{array}$ & $\begin{array}{c}\text { Elevation } \\
\text { Relative to Sea } \\
\text { Level }\end{array}$ & $\begin{array}{c}\text { Tidal } \\
\text { Inundation } \\
\text { Level }\end{array}$ & Sediment Feature & $\begin{array}{l}\text { Freshwater } \\
\text { Inflow }\end{array}$ \\
\hline Estuarine & $\begin{array}{l}\text { Low and } \\
\text { intermediate }\end{array}$ & $\begin{array}{l}\text { Frequently } \\
\text { waterlogged, } \\
\text { inundated at } \\
\text { low tide }\end{array}$ & $\begin{array}{l}\text { Dominated by fine } \\
\text { sediment and deep } \\
\text { surface substrate }\end{array}$ & From rivers \\
\hline Seaward fringe & Low & $\begin{array}{l}\text { Inundated at } \\
\text { almost all tide } \\
\text { levels }\end{array}$ & $\begin{array}{l}\text { Dominated by sand with } \\
\text { small proportion of fine } \\
\text { sediments, various } \\
\text { depths of surface } \\
\text { substrate }\end{array}$ & Absent \\
\hline $\begin{array}{l}\text { Coralline sand } \\
\text { berm }\end{array}$ & Low & $\begin{array}{l}\text { Inundated at } \\
\text { almost tide } \\
\text { levels }\end{array}$ & Coralline sand berm & Absent \\
\hline $\begin{array}{l}\text { Seaward young } \\
\text { soil }\end{array}$ & Low & $\begin{array}{l}\text { Inundated at } \\
\text { almost tide } \\
\text { levels }\end{array}$ & $\begin{array}{l}\text { Fine sediments from } \\
\text { river mouth }\end{array}$ & From river \\
\hline
\end{tabular}




\begin{tabular}{|c|c|c|c|c|}
\hline $\begin{array}{l}\text { Sub-habitat } \\
\text { Types }\end{array}$ & $\begin{array}{c}\text { Elevation } \\
\text { Relative to Sea } \\
\text { Level }\end{array}$ & $\begin{array}{c}\text { Tidal } \\
\text { Inundation } \\
\text { Level }\end{array}$ & Sediment Feature & $\begin{array}{l}\text { Freshwater } \\
\text { Inflow }\end{array}$ \\
\hline $\begin{array}{l}\text { Very stable } \\
\text { middle zone }\end{array}$ & Intermediate & $\begin{array}{l}\text { Inundated at } \\
\text { neap and } \\
\text { spring tides }\end{array}$ & $\begin{array}{l}\text { Dominated by organic } \\
\text { materials }\end{array}$ & $\begin{array}{l}\text { Less } \\
\text { influence } \\
\text { from } \\
\text { seepage }\end{array}$ \\
\hline $\begin{array}{l}\text { Less steep and } \\
\text { eroding } \\
\text { landward zone }\end{array}$ & High & $\begin{array}{l}\text { Inundated at } \\
\text { spring tide }\end{array}$ & $\begin{array}{l}\text { Dominated by fine sand, } \\
\text { shallow surface } \\
\text { substrate }\end{array}$ & $\begin{array}{l}\text { Seasonally } \\
\text { from } \\
\text { seepage }\end{array}$ \\
\hline $\begin{array}{l}\text { Highly } \\
\text { accreting } \\
\text { inland fringe }\end{array}$ & High & $\begin{array}{l}\text { Inundated } \\
\text { only at } \\
\text { maximum } \\
\text { high tide }\end{array}$ & $\begin{array}{l}\text { Dominated by sediments } \\
\text { from the vicinity land }\end{array}$ & $\begin{array}{l}\text { Seasonally } \\
\text { from } \\
\text { seepage }\end{array}$ \\
\hline $\begin{array}{l}\text { Seasonally or } \\
\text { regularly } \\
\text { freshwater } \\
\text { influenced } \\
\text { landward zone }\end{array}$ & High & $\begin{array}{l}\text { Inundated at } \\
\text { spring tide }\end{array}$ & $\begin{array}{l}\text { Dominated by fine sand } \\
\text { and subjected to } \\
\text { sedimentation from land }\end{array}$ & $\begin{array}{l}\text { From water } \\
\text { table and } \\
\text { seepage }\end{array}$ \\
\hline Seaward beach & High & $\begin{array}{l}\text { Dry at almost } \\
\text { tide levels }\end{array}$ & $\begin{array}{l}\text { Dominated by coarse } \\
\text { sands }\end{array}$ & Absent \\
\hline
\end{tabular}

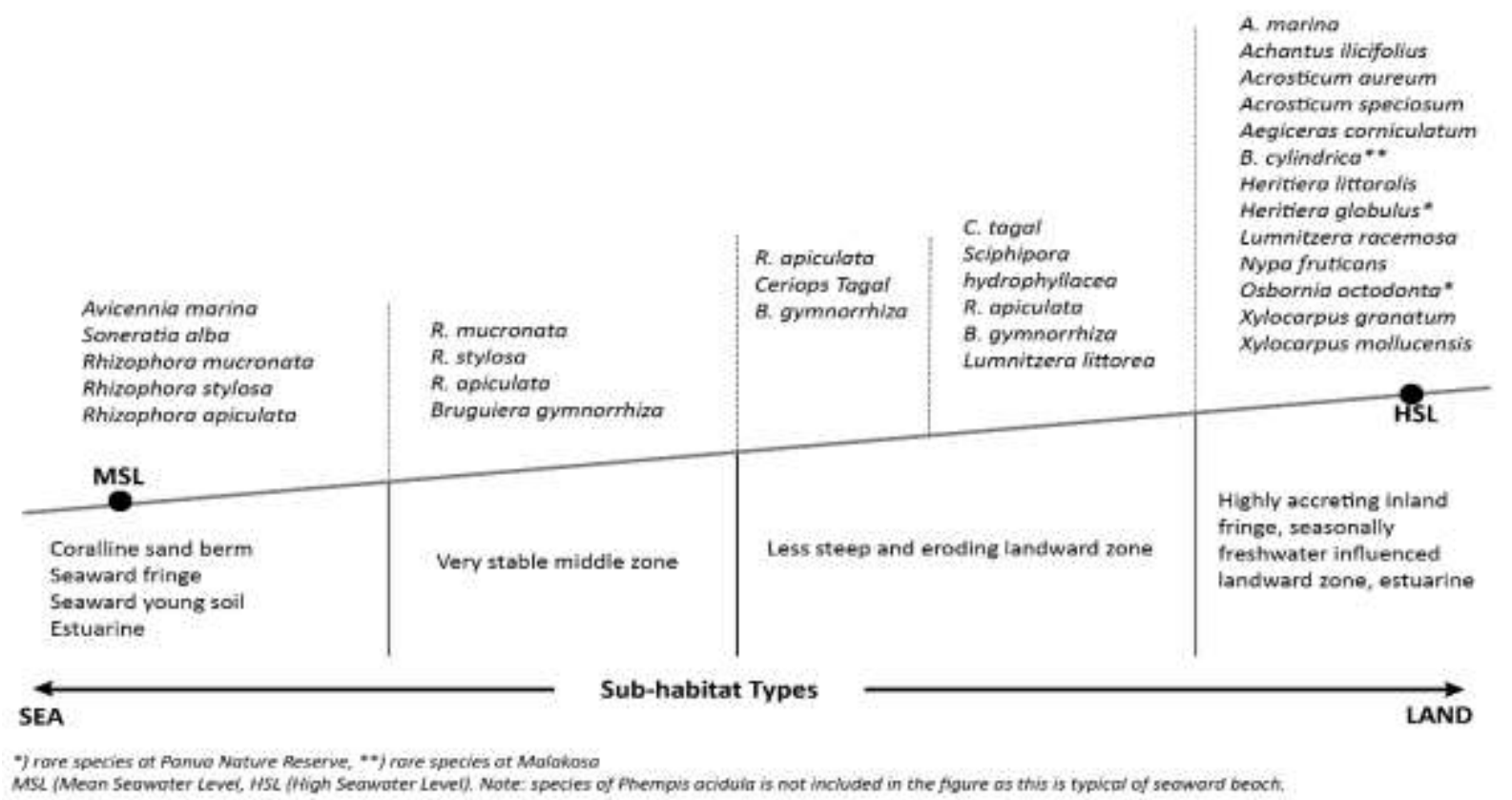

Figure 3. The relative position of mangrove sub-habitats across intertidal environment and species composition over different types of sub-habitat.

As can be seen from Figure 3, two species, Bruguiera gymnorrhiza and Rhizophora apiculata, seemed to have been common on several habitat types. Other species occured on specific sub-habitats but in large numbers such as Ceriops tagal, Pempis acidula, Sonneratia alba and $S$. hydrophyllacea. Meanwhile, three species, Bruguiera cylindrica, O. octodonta, and $H$. 
globulus, occurred only on specific subhabitats in small numbers.

\subsection{Association Types and Structural Formations}

Tomini Gulf mangrove forest exhibited some major changes in habitat conditions over spatial scale. Using the floristic properties in the dominant canopy, types of mangrove assosiaciation were identified, and to classify the plant formation two ways structural classification of Specht (1970) was followed. Tabel 4 summarises ten types of mangrove association with each structural classes over various sub-habitat types.

Trees of Avicennia marina occured on two types of sub-habitat of highly accreting inland fringe and seward young soil. On highly accreting inland fringe stands were more likely in the formations of forest and closed-forest. On seaward young soil, they were found in low closed-shrub and closed-forest formations. Forest with dominant canopy species of B. gymnorrhiza was uncommon. At Lopon $\left(00^{\circ} 25.722^{\prime} \mathrm{N}\right.$; $124^{\circ} 6.203^{\prime}$ E), a mono-species stand of $B$. gymnorrhiza was in closed-forest formation with average canopy height of $25 \mathrm{~m}$ and diameter varying from $37-48 \mathrm{~cm}$. The association of $C$. tagal was common on less steep and eroding lardward where surface substrate water salinity is usually high (Djamaluddin, 2018). At Pinolantungan $\left(00^{\circ} 21^{\prime} 31.8^{\prime \prime} \mathrm{N} ; 1^{\circ} 3^{\circ} 56^{\prime} 29.7^{\prime \prime} \mathrm{E}\right)$, stands of C. tagal occured in the formation of tall closed-shrub.

It was very common that stands of $N$. fruticans occured in mono-species stands in seasonally or regularly freshwater influenced landward zone. In Tomini Gulf, this association tipe was found, for example at Dagad Dede $\left(00^{\circ} 25^{\prime} 55.6^{\prime \prime} \mathrm{N}\right.$; 120 $20^{\circ} 4^{\prime} 22.4^{\prime \prime}$ E) and Matandow.

Tabel 4. Mangrove associations and structural formations over various types of sub-habitat.

\begin{tabular}{|c|c|c|}
\hline Association Type & Structural Classes & Sub-habitat Types \\
\hline Avicennia marina & $\begin{array}{l}\text { Closed-forest, forest, low } \\
\text { closed-shrub }\end{array}$ & $\begin{array}{l}\text { Highly accreting inland fringe, } \\
\text { seaward young soil }\end{array}$ \\
\hline B. gymnorrhiza & Closed-forest & Very stable middle zone \\
\hline C. tagal & $\begin{array}{l}\text { Tall closed-shrub, tall open- } \\
\text { shrub, tall sparse-shrub, low } \\
\text { open-shrub }\end{array}$ & Less steep and eroding landward \\
\hline Nypa fruticans & - & $\begin{array}{l}\text { Seasonally or regularly } \\
\text { freshwater influenced landward } \\
\text { zone }\end{array}$ \\
\hline $\begin{array}{l}\text { Rhizophora spp./B. } \\
\text { gymnorrhiza }\end{array}$ & $\begin{array}{l}\text { Forest, closed-forest, low } \\
\text { closed-forest }\end{array}$ & Very stable middle zone \\
\hline R. apiculata/C. tagal & $\begin{array}{l}\text { Closed-forest, Low forest, low } \\
\text { open-forest, low closed-forest }\end{array}$ & $\begin{array}{l}\text { Less steep and eroding landward } \\
\text { zone }\end{array}$ \\
\hline Rhizophora spp. & $\begin{array}{l}\text { Forest, low open-forest, low } \\
\text { forest, low closed-forest }\end{array}$ & $\begin{array}{l}\text { Seaward fringe, coralline sand } \\
\text { berm, seaward young soil }\end{array}$ \\
\hline Sonneratia alba & $\begin{array}{l}\text { Tall closed-forest, closed- } \\
\text { forest, forest, low closed-forest }\end{array}$ & $\begin{array}{l}\text { Seaward fringe, coralline sand } \\
\text { berm, seaward young soil }\end{array}$ \\
\hline $\begin{array}{l}\text { S. alba/B. } \\
\text { gymnorrhiza }\end{array}$ & Tall closed-forest & $\begin{array}{l}\text { Very stable middle zone, } \\
\text { coralline sand berm }\end{array}$ \\
\hline $\begin{array}{l}\text { S. alba/ Rhizophora } \\
\text { spp. }\end{array}$ & $\begin{array}{l}\text { Forest, closed-forest, low- } \\
\text { closed forest }\end{array}$ & $\begin{array}{l}\text { Seaward fringe, coraline sand } \\
\text { berm, seaward young soil }\end{array}$ \\
\hline S. alba/ A. marina & Forest & Seaward fringe \\
\hline
\end{tabular}


When Rhizophora spp. $B$. gymnorrhiza association type occured, it was most probable that the sub-habitat condition was physically stable (Djamaluddin, 2018). At Patoa (00'19'57,2" N; 12351'19" E) forest and closed-forest formations were found with canopy height in the range between 15.5 and $23.3 \mathrm{~m}$ and tree diameter up to $101 \mathrm{~cm}$. The association of $R$. apiculata / C. tagal was encountered in closed-forest, low forest, low open-forest, low closed-forest formations. At Dudepo (0001'56.6" N; $123^{\circ} 55^{\prime} 09.5^{\prime}$ E), canopy trees of $R$. apiculata and C. tagal occured in low forest formation.

Stands of Rhizophora spp. usually occured on seaward fringe and young soil sub-habitats. In Tomini Gulf this association was encountered in forest, low open-forest, low forest, and low closed-forest formations. Mono-stand of $S$. alba was common on seaward fringe, coralline sand berm, seaward young soil sub-habitats. At Pangia $\left(00^{\circ} 19^{\prime} 16.2^{\prime \prime} \quad \mathrm{N} ; 1^{\circ} 47^{\circ} 57.2^{\prime \prime} \quad\right.$ E) this association occured in tall closed-forest formation. The Sonneratia alba/B. gymnorrhiza association occurred only on very stable coastal environment such as at Duminanga $\left(00^{\circ} 19^{\prime} 43.2^{\prime \prime} \mathrm{N}\right.$; 12350'53.6" E). In this location the formation was encountered in tall closed-forest formation. The $S$. alba/Rhizophora spp. association occured on seaward fringe. At Dusun Langala $\left(00^{\circ} 30^{\prime} 5.6 \mathrm{~N} ; 1^{\circ} 28^{\prime} 53.5^{\prime \prime} \quad\right.$ E) stands consisted of $S$. alba, R. apiculata and $R$. stylosa. The $S$. alba/A. marina association was found at Ongka $\left(00^{\circ} 28^{\prime} \quad 15.9^{\prime \prime} \mathrm{N}\right.$; $\left.120^{\circ} 47^{\prime} 35.8^{\prime \prime} \mathrm{E}\right)$ on a relatively stable intertidal environment. Canopy trees consisted of two species of $S$. alba and A. marina in a forest formation with canopy height of $11.7 \mathrm{~m}$.

\subsection{Patterns in Uses and Level of Disturbance}

During 1988 to 2010 the Gulf had lost mangrove area of some 42\% (10 787.66 Ha or $107.88 \mathrm{~km}^{2}$ ) with the average rate of loss at the level of $578.36 \mathrm{ha} /$ year. If this level of degradation would be continual, and there are not any efforts to rehabilitate and conserve the mangroves, the whole remaining area of $16,105.40$ ha will vanish in 2038 (Damanik and Djamaluddin, 2012). Although most of shrimp ponds were abandoned, it was revealed in the field that there were new shrimp ponds even in Tanjung Panjang Nature Reserve (Figure 4 A). Most of abandoned shrimp ponds remained unvegetated due to the change in hydrological condition and high soil salinity (Figure 4 B). Moreover, the release of sediments from area of shrimp ponds occured persistently and this resulted in sedimentation on coastal ecosystems such as seagrass and coral reefs.
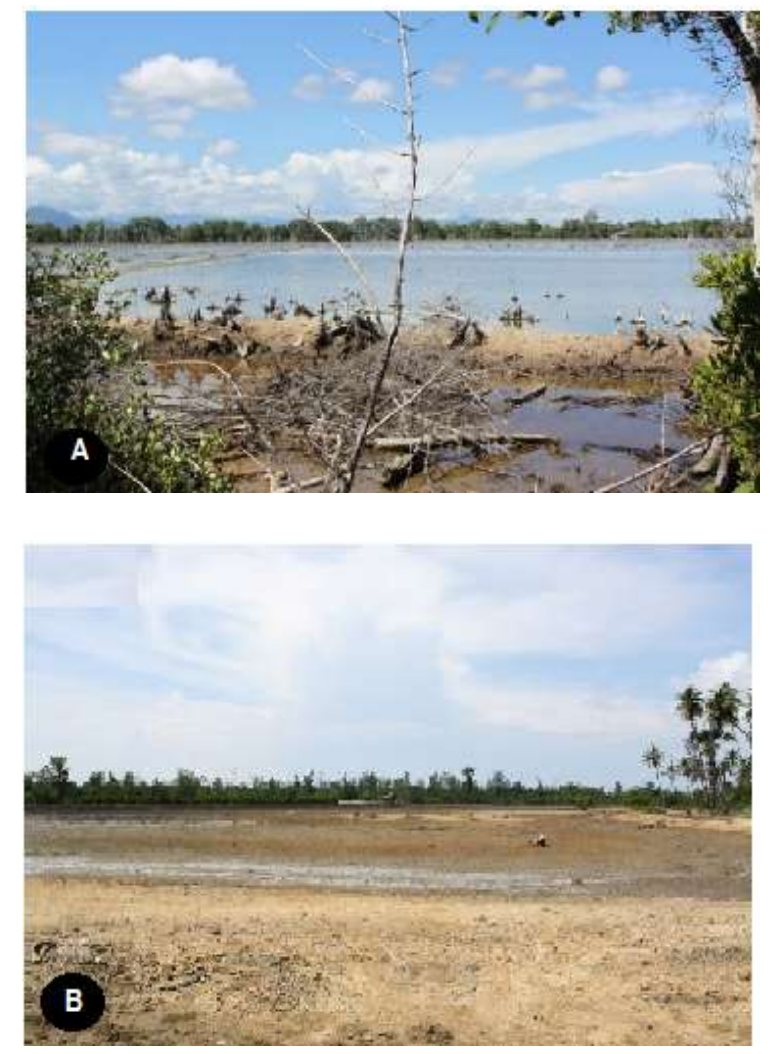

Figure 4. New established shrimp pond: (a) Tanjung Panjang Nature Reserve (b) Bajo.

Local people exploited mangrove wood for various purposes. Most of big trees 
of $S$. alba had been cut to meet the need of timber for fishing boat construction (Figure 5 A), resulting in forest with remaining hollow trunk big trees. Unlike wood of $S$. alba, big trees of B. gymnorrhiza were cut to provide timber for construction of lift net (Figure 5 B). There was also significant evidence that trees of B. gymnorrhiza and Rhizophora spp. were subjected to ring-barking to meet the need for fish net preservation and colouring (Figure $5 \mathrm{C}$ ). This, however, had left the forest with standing dead trees of both species in certain locations. Wood of these species had also been targeted for firewood (Figure $5 \mathrm{D}$ ). Other uses of mangrove were for stakes of fish trap and fence (Figure $5 \mathrm{E}$, F).

From the total 159 locations surveyed some $40.3 \%$ and $35.2 \%$ were classified under medium and light disturbed condition respectively, seven location (4.4\%) undisturbed and three locations $(2 \%)$ at level of heavy and very heavy disturbance. This result of evaluation indicated that almost all types of forest associations had been subjected to mangrove exploitation, and the exploitation had been widespread. If the current level of exploitation continue and spread this ecosystem will experience serious damage and will lose its ecological functions.

\subsection{Field Implication of Artificial Plantation}

All rehabilitation projects examined in this study applied method of artificial plantation with mostly seedlings of Rhizophora spp. from nursery, and facts in the field indicated that most of these projects had been unsuccessful. At Duminanga, seedlings of Rhizophora spp were planted in open spaces within a dense forest where the natural regeneration process was most probable (Figure 6 A). At Dudepo, goat grazing had resulted in the loss of almost all planted seedlings (Figure $6 \mathrm{~B}$ ). At Tanjung Bendera, most of seedlings of Rhizophora spp. disappeared due to sedimentation and abrasion and the presence of free-moving $\operatorname{logs}$ in the location (Figure $6 \mathrm{C}$ ). There were only a few rehabilitation programs that had been sucessful such as at Boila River mouth (Figure 6 D).
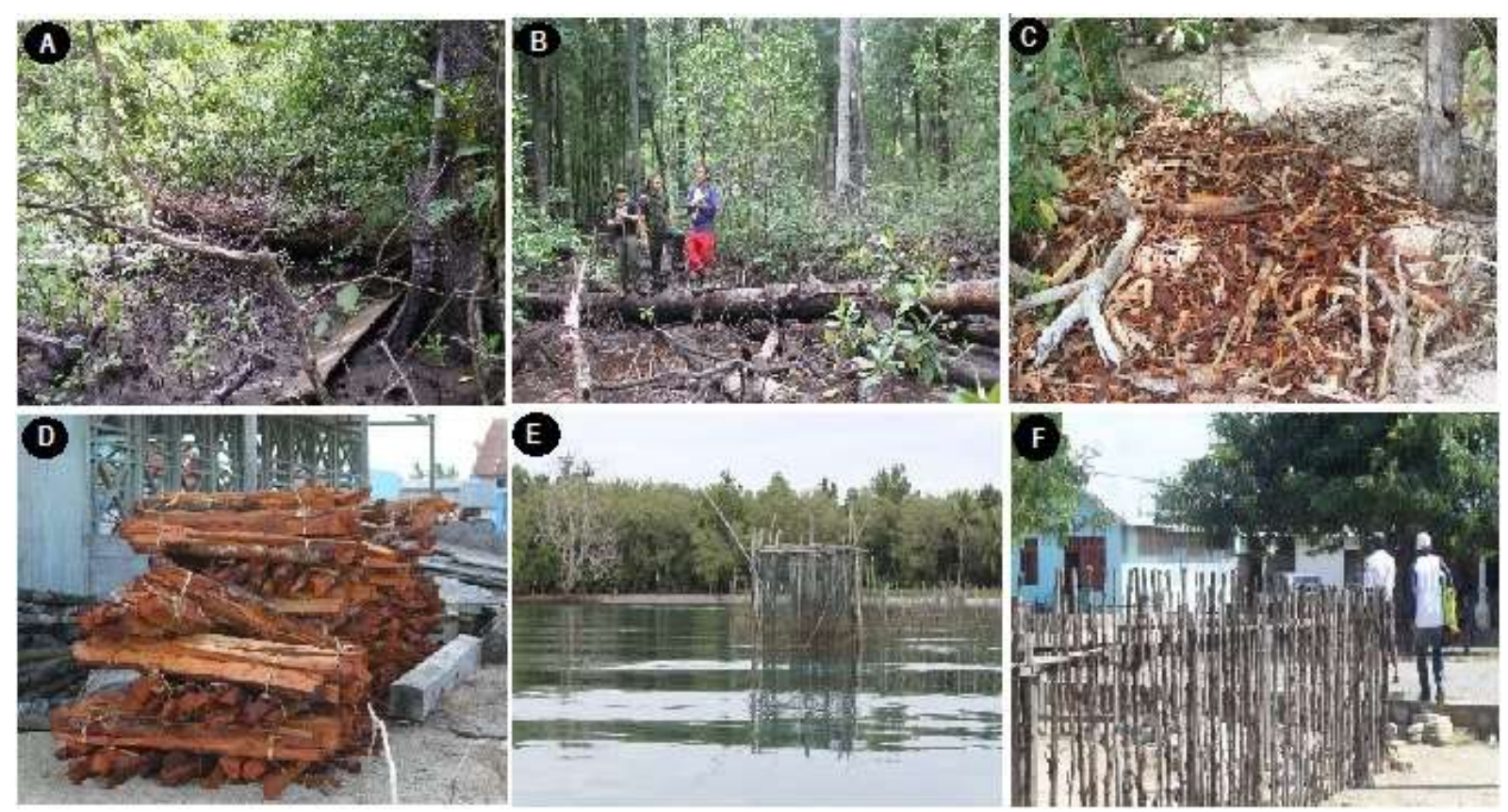

Figure 5. Mangrove uses: (a) logging S. alba, (b) logging B. gymnorrhiza, (c) mangrove bark, (d) fire wood, (e) fish trap, (f) fence. 

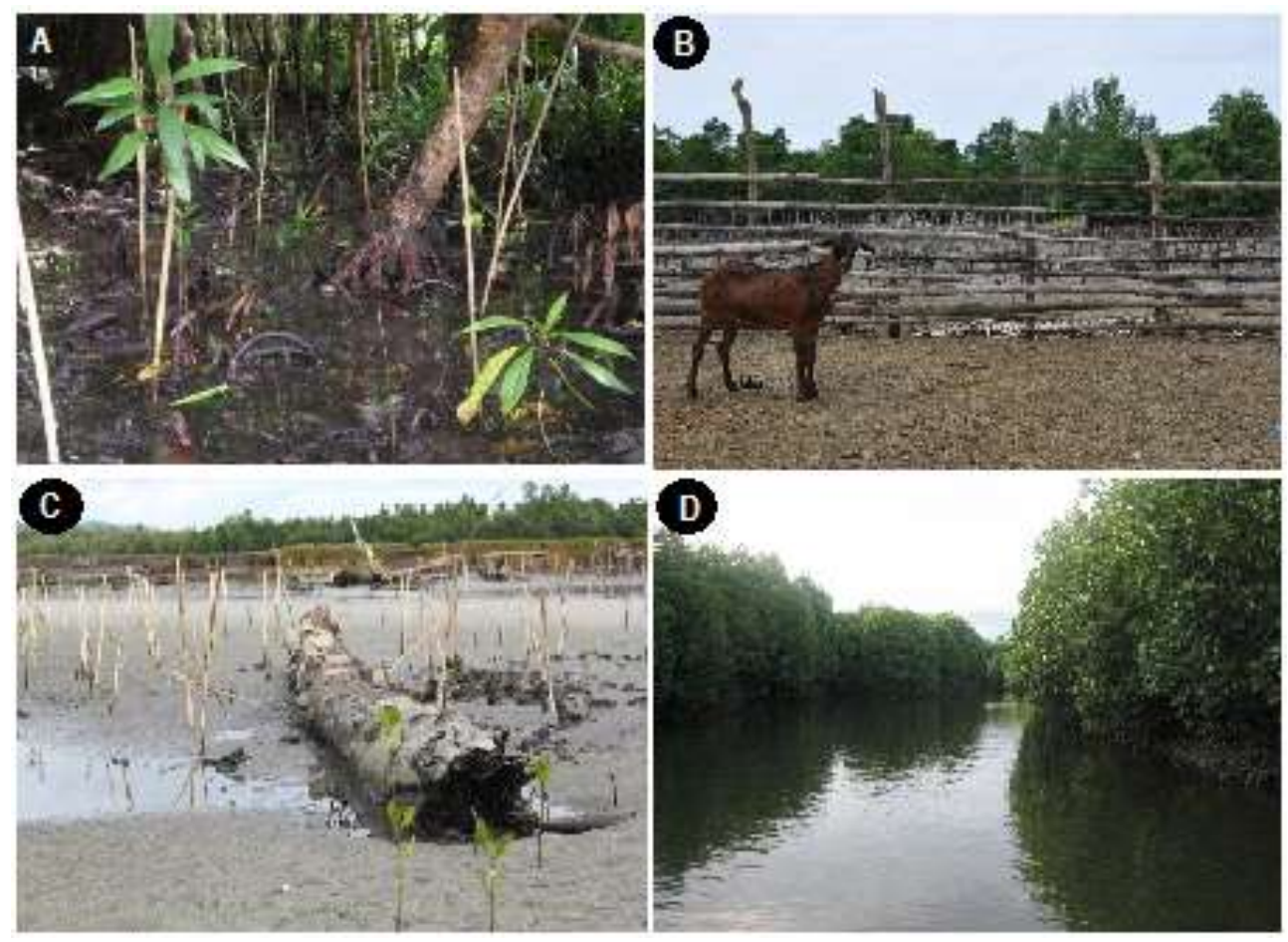

Figure 6. Artificial plantation in: (a) Duminanga, (b) Dudepo, (c) Tanjung Bendera, (d) Boila River mouth.

Unsucessful mangrove rehabilitation programs in Tomini Gulf clarify that artificial plantation is not a simple method to be implemented on degraded mangrove areas and areas subjected to active coastal physical processes. Over all, proper procedure and techniques related to artificial mangrove plantation have to be followed, and hydrological restoration may be adopted to rehabilitate physically degraded mangrove areas.

\section{CONCLUSION}

Conversion of mangrove areas into shrimp ponds and extraction of mangrove wood for various purposes had changed vegetation structure over various subhabitats, influencing future development and regeneration of the mangrove. Whilst most of rehabilitation programs were unsuccessful, mangrove exploitations still continued. If management plan would not be developed the degradation will continue and spread, then the mangrove may lose its ecological function.

\section{ACKNOWLEGMENT}

I am thankful to IUCN for providing fund and facilities. Field work could not be completed without assistance offered by staffs of Kelola Manado, Asosiasi Nelayan Tradisional (Antra) Sulut, Japesda Gorontalo, Yasalu Parigi Moutong, Mangrove Task Forces in Bolaang Mongondow Selatan, Boalemo, Pohuwato and Parigi Moutong Regencies. I also thank to Darren O'Connell for helpful edits.

\section{REFERENCES}

Bandaranayake, M.M. 1998 Traditional and medical uses of mangrove. Mangroves and Salt Marshes, 2(3): 133-148.

http://doi.org/10.0023/A:1009988070 44 
Blasco, F. 1984. Taxonomic considerations of the mangrove species. In: Snedaker, S.C. and Snedaker, J.G. (eds.). The mangrove ecosystem: research methods, UNESCO. 8-90 pp.

Brown, B. and R. Djamaluddin. 2017. A site history and field guide for ecological mangrove rehabilitation in tiwoho Village, Bunaken National Park, North Sulawesi, Indonesia. Center for International Forestry Research. Bogor. 35 p.

Clarke, L.D. and N.J. Hannon. 1969. Mangrove swamp and salt marsh communities of the Sydney District: the holocoenotic complex with particular reference to physiography. J. Ecol., 57: 213-34. http://doi.org/10.2307/2258216

Damanik, R. and R. Djamaluddin. 2012. Atlas mangrove Teluk Tomini. Sustainable Coastal Livelihoods and Management Program, CIDA, IUCN, Lestari Canada. 91 hlm.

Davie, J., R. Merril, and R. Djamaluddin. 1996. The sustainable use and conservation of the mangrove ecosystem of the Bunaken National Park. USAID, Jakarta.

Ding-Hou, L. 1958. Rhizophoraceae. In: van Steenis, C.G.G.J. (ed.). Flora Malesiana Series I Volume 5. Noordhoff - Kolff N. V. Djakarta. 429-493 pp.

Djamaluddin, R. 2004. The dynamics of mangrove forest in relation to dieback and human use in Bunaken National Park, North Sulawesi, Indonesia. Dissertation. The University of Queensland. 325p.

Djamaluddin, R. 2015. Mangrove flora in Tomini Bay - Indonesia. In: Widodo et al. (eds.). Proceeding the $5^{\text {th }}$ international conference on plant diversity (plant diversity: A Global Challenge), Graha Widyatama, Universitas Jenderal Soedirman,
Purwokerto, 2021 August 2015. 36$42 \mathrm{pp}$.

Djamaluddin, R. 2018. The mangrove flora and their physical habitat characteristics in Bunaken National Park, North Sulawesi, Indonesia. Biodiversitas, 19(4): 1303-1312. https://smujo.id/biodiv/article/view/2 78

Duke, N., K. Kathiresan, S.G. Salmo III, E.S. Fernando, J.R. Peras, S. Sukardjo, and T. Miyagi. 2010. Ceriops zippeliana. IUCN Red List of Threatened Species Version 2014.3. International Union for Conservation of Nature and Natural Resources.

Fernando, E.S. and J.V. Pancho. 1980. Mangrove trees of the Philippines. Silvatrop Philipp. For. Res. J., 5(1): 35-54.

Gieasen, W., S. Wulffraat, M. Zieren, and L. Scholten. 2006. Mangrove guide book for Southeast Asia. FAO and Wetlands International.

Hamilton, S.E, and D. Casey. 2016. Creation of a high spatio-temporal resolution global database of continuous mangrove forest cover for the 21st century (CGMFC-21). Glob Ecol Biogeogr., 25 (6): 729-738. http://doi.org/10.1111/geb.12449

Hendrawan, Gaol, J.L., and S.B. Susilo. 2018. Studi kerapatan dan perubahan tutupan mangrove menggunakan citra satelit di Pulau Sebatik Kalimantan Utara. J. Ilmu dan Teknologi Kelautan Tropis, 10(1): 99-109. http://doi.org/10.29244/jitkt.v10i1.18 595

Hidayat, J.W. 2013. Pengendalian wideng (Sesarma spp.) sebagai hama melalui pendekatan ko-manajemen: studi kasus di tambak Desa Tapak Tugurejo, Semarang. J. Sains dan Matematika, 21(3): 54-61.

Koch, E.W., E.B. Barbier, B.R. Silliman, D.J. Reed, G.M.E. Perilos, S.D. Hacker, E.F. Granek, J.H. 
Primaveras, N. Muthiga, S. Polasky, B.S. Halpern, C.J. Kennedy, C.V. Kappel, and E. Wolanski. 2009. Non-linearity in ecosystem service: temporal and spatial variability in coastal protection. Fron. Ecol. Envir., 7(1): 29-37.

http://doi.org/10.1890/0801126

Lewis, R.R. 2005 Ecological engineering for successful management and restoration of mangrove forests. Ecol. Engineering, 24: 403-418. http://doi.org/10.1016/j.ecoleng.2004. 10.003

Mabberley, C.M., C.M. Pannel, and A.M. Sing. 1995. Flora Malesiana: Seri I Spermathophyata, 12(1): 371-81.

Margono, B.A., P.V. Potapov, S. Turubanova, F. Stolle, and M.C. Hansen. 2014. Primary forest cover loss in Indonesia over 2000-2012. Nat. Climate Change, Published Online 29 June 2014. http://doi.org/10.1038/NCLIMATE22 77

Maxwell, G.S. 2015. Gaps in mangrove science. ISME/GLOMIS, 13(5):18-38.

Murdiyarso, D., J. Purbopuspito, J.B. Kauffman, M. Warren, S. Sasmito, D. Donato, and S. Kurnianto. 2015. The potential of Indonesian mangrove forests for global climate change mitigation. Nat. Climate Change, 5: 1089-1092.

http://doi.org/10.1038/nclimate2734

Noor, Y.R., M. Khazali, I.N.N. and Suryadiputra. 2006. Panduan pengenalan mangrove. Ditjen PPHKA-Wetland International. Bogor. $220 \mathrm{hlm}$.

Percival, M. and J.S. Womersley. 1975. Floristics and ecology of the mangrove vegetation in Papua New Guinea. Bot. Bull., 8. Department of Forest. Lae. 96p.

Priyono, A. 2010. Panduan praktis teknik rehabilitasi mangrove di pesisir
Indonesia. KeSEMaT. Semarang. 49 hlm.

Richards, D.R, and D.A Fries. 2016 Rates and drivers of mangrove deforestation in Southeast Asia 2000-2012. Proc Natl Acad Sci USA, 113(2): 344-349. http://doi.org/10.1073.pnas.15102721 13

Sheue, C.R., H.Y. Liu, C.C. Tsai, S.M.A. Rashid, J.W.H. Yong, and Y.P. Yang. 2009. On the morphology and molecular basis of segregation of Ceriops zippeliana and $C$. decandra (Rhizophoraceae) from Asia. Blumea, 54: 220-227.

http://doi.org/10.3767/000651909X47 6193

Spalding, M.D., M. Kainuma, and L. Collins. 2010. World Atlas of Mangroves. Earthscan. London.

Specht, R.L. 1970. Vegetation. In: Leeper, G.W. (ed.). Australian Environment. Melbourne University Press. Melbourne. 44-67pp.

Thom, B.G. 1967. Mangrove ecology and deltaic geomorphology, Tobasco, Mexico. J. Ecology, 55: 301-43. http://doi.org/10.2307/2257879

Thom, B.G. 1982. Mangrove ecology - a geomorphological perspective. In: Clough, B.F. (ed.). Mangrove ecosystem in Australia: Structure, Function and Management. Canberra (Australia), AIMS with ANU press. 3-17pp.

Tomlinson, P.B. 1986. The botany of mangroves. Cambridge University Press, New York. 413p.

Valiela, I., J.L. Bowen, and Y.K. York. 2001. Mangrove forests: one of the world's threatened major tropical environments. BioScience, 51(10): 807-815. http://doi.org/10.1641/0006-3568

Walker, J. and M.S. Hopkins. 1990. Vegetation. In: McDonald et al. (eds.). Australian Soil and Land 
Survey: Field Handbook. Mellbourne (Australia), Inkata Press. 58-86 pp.

Wibisono, I.T.C. 2016. Kajian Kelayakan dan Pengembangan Desain Teknis Rehabilitasi Pesisir. Working paper 227. World Agroforestry Centre (ICRAF) Southeast Asia Regional Program, Bogor.

http://doi.org/10.5716/WP16037.PDF
Winkword, R.E., and D.W. Goodall. 1962. A crosswire sighting tube for points quadrate analyses. J. Ecology, 43: 342-43.

http://doi.org/10.2307/1931997

Received : 30 August 2019

Reviewed : 13 September 2019

Accepted : 15 November 2019 